\title{
ACTIVITIES FOR THE INTERNATIONAL FEDERATION OF SURGICAL COLLEGES
}

\author{
Professor J. F. Nuboer, Utrecht, Holland
}

The International Federation of Surgical Colleges and Kindred Societies was founded in Stockholm in 1958 as the result of a joint initiative of the American College of Surgeons and the Royal College of Surgeons of England.

The intention of the Federation was to constitute a new type of international surgical group with a different composition and other aims than the existing international surgical societies. Membership was to be confined to national surgical societies. The Federation was not intended to be a "Congress Organising Body," but was to direct its activities towards promoting closer and more amicable contact between national societies, the coordination of training programmes, international research, assistance in exchange of young surgeons and where necessary and desirable the organisation of surgical missions.

This was no mean task that the federation had set itself. To realise these aims it was essential to choose as first president someone who could bring the devotion and tact needed to help this new baby of the family of international societies safely and soundly through the first few difficult years.

By unanimous agreement Sir Harry Platt was chosen as the most capable person to take up this difficult task. In all respects this was a most excellent choice. Under his leadership, with the able support of Kennedy Cassels as energetic secretary, and originally by Ravdin and Dahl-Iversen, later by Englebert Dunphy and Carl Semb as vice-presidents, the Federation has gradually but steadily grown and has now thirty-eight members.

In his characteristic way Sir Harry has allowed the Federation to seek the road along which it wished to develop, without forcing his own opinions on others. Thanks to his care, this delicate baby has grown up to be a healthy child with a character all its own. When, in the future, the Federation grows to healthy adulthood, the thanks will be due above all to the tact and fatherly care displayed by Sir Harry in the performance of his task. Those who have been able to follow his work as closely as I have, and from the very beginning, will know how much surgery over the whole world owes to him.

May he look back on this work with satisfaction.

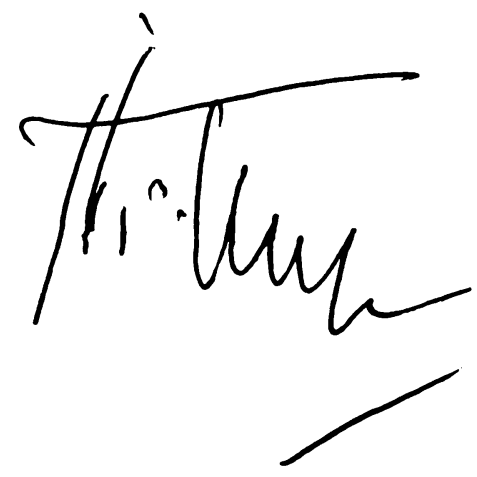

